\title{
Water vapour variability in the high-latitude upper troposphere - Part 2: Impact of volcanic eruptions
}

\author{
Christopher E. Sioris ${ }^{1}$, Jason Zou ${ }^{2}$, C. Thomas McElroy ${ }^{1}$, Chris D. Boone ${ }^{3}$, Patrick E. Sheese ${ }^{2}$, and Peter F. Bernath ${ }^{3,4}$ \\ ${ }^{1}$ Department of Earth and Space Science and Engineering, York University, Toronto, Canada, 4700 Keele St., Toronto, ON, \\ M3J 1P3, Canada \\ ${ }^{2}$ Department of Physics, University of Toronto, 60 St. George. St., Toronto, ON, M5S 1A7, Canada \\ ${ }^{3}$ Department of Chemistry, University of Waterloo, 200 University Ave. W, Waterloo, ON, N2L 3G1, Canada \\ ${ }^{4}$ Department of Chemistry \& Biochemistry, Old Dominion University, 4541 Hampton Blvd., Norfolk, VA 23529, USA \\ Correspondence to: Christopher E. Sioris (csioris@sdcnlab.esse.yorku.ca)
}

Received: 24 July 2015 - Published in Atmos. Chem. Phys. Discuss.: 24 September 2015

Revised: 31 January 2016 - Accepted: 5 February 2016 - Published: 25 February 2016

\begin{abstract}
The impact of volcanic eruptions on water vapour in the high-latitude upper troposphere is studied using deseasonalized time series based on observations by the Atmospheric Chemistry Experiment (ACE) water vapour sensors, namely MAESTRO (Measurements of Aerosol Extinction in the Stratosphere and Troposphere Retrieved by Occultation) and the Fourier Transform Spectrometer (ACE-FTS). The two eruptions with the greatest impact on the high-latitude upper troposphere during the time frame of this satellitebased remote sensing mission are chosen. The PuyehueCordón Caulle volcanic eruption in June 2011 was the most explosive in the past 24 years and is shown to be able to account for the observed $(50 \pm 12) \%$ increase in water vapour in the southern high-latitude upper troposphere in July 2011 after a minor adjustment for the simultaneous influence of the Antarctic oscillation. Eyjafjallajökull erupted in the spring of 2010, increasing water vapour in the upper troposphere at northern high latitudes significantly for a period of $\sim 1$ month. These findings imply that extratropical volcanic eruptions in windy environments can lead to significant perturbations to high-latitude upper tropospheric humidity mostly due to entrainment of lower tropospheric moisture by windblown plumes. The Puyehue-Cordón Caulle eruption must be taken into account to properly determine the magnitude of the trend in southern high-latitude upper tropospheric water vapour over the last decade.
\end{abstract}

\section{Introduction}

Water vapour in the tropopause region is particularly effective at trapping outgoing longwave radiation emitted by the surface (Solomon et al., 2010). Currently, trends in upper tropospheric water vapour (UTWV) are not known for high latitudes (Hartmann et al., 2013). The first step toward accurate trends is to improve our understanding of UTWV variability at high latitudes. The variability of upper tropospheric water vapour (UTWV) at high latitudes is dominated by dynamics (Sioris et al., 2015). In this companion paper, a second phenomenon is identified that contributes secondarily to the variability of UTWV: volcanic eruptions. The importance of volcanic eruptions relative to other dynamical and thermodynamic processes in this region on monthly timescales is an open question which motivates this study. Water vapour is the most abundant volcanic gas, comprising over $80 \%$ by volume (Pinto et al., 1989). UTWV was observed to decrease following the 1991 Pinatubo eruption due to global cooling below the tropopause and did not return to normal levels for 2 years (Soden et al., 2002). However, based on Microwave Limb Sounder observations, increases of up to $18 \%$ in water vapour in the southern hemispheric tropopause region (300$100 \mathrm{hPa}$ ) during April-December 1992 were attributed to the eruption of Pinatubo but could not be simulated (Forster and Collins, 2004). In the southern high-latitude tropopause region, increases of $\sim 10 \%$ were observed over the same time period and are more relevant to this study. For volcanoes with an eruption height at or below tropopause, local warming by 


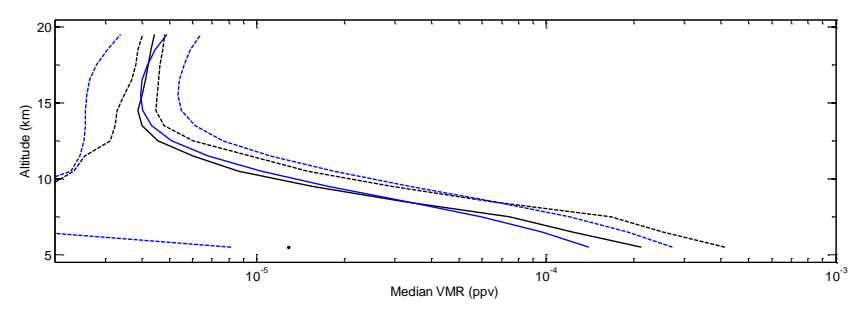

Figure 1. Comparison of global median water vapour volume mixing ratios (VMRs) from MAESTRO (blue) and ACE-FTS (black) $(N=15000)$. The solid lines are the median profiles, while the dashed lines bracket \pm 1.48 median absolute deviations (MAD) about the median.

radiation-absorbing volcanic aerosols such as ash can lead to local increases in water vapour in response. The timescale of UTWV enhancement due to such a thermal mechanism would be controlled by rainout and fallout of the aerosol, which is of the order of $\sim 1$ month (Prospero, 1983; Pruppacher and Klett, 2010) for particles of intermediate size $(\sim 0.3 \mu \mathrm{m})$. Water vapour at the tropopause has a typical atmospheric residence time of the order of 3 weeks based on mid-latitude observations (Ehhalt, 1973) and is of the order of a month at high latitudes (Grewe and Stenke, 2008). Water vapour is mostly removed by precipitation (Junge, 1963). The residence time decreases to $\sim 2$ weeks at an altitude of $5 \mathrm{~km}$ (Ehhalt, 1973), which limits the distance over which UTWV enhancements can be advected.

Below we present the satellite-based observations of relatively large increases in UTWV in both high-latitude regions following recent smaller volcanic eruptions. Also in contrast to Pinatubo-related UTWV changes, the enhancements presented below occur in the month after eruption and then diminish exponentially.

\section{Methods}

SCISAT was launched in 2003 (Bernath et al., 2005) and the Atmospheric Chemistry Experiment (ACE) data sets begin in February 2004. The satellite bears two limb sounders measuring water vapour that both rely on the solar occultation technique: Measurements of Aerosol Extinction in the Stratosphere and Troposphere Retrieved by Occultation (MAESTRO, McElroy et al., 2007) and the Fourier Transform Spectrometer (ACE-FTS) as well as an Imager (Bernath et al., 2005) which provides aerosol extinction measurements (e.g. Vanhellemont et al., 2008) that can be directly compared with those retrieved from MAESTRO observations. MAESTRO is currently the only satellite instrument capable of simultaneously measuring vertical profiles of both water vapour and extinction by fine aerosols (Sioris et al., 2010b) down to the mid-troposphere. The MAESTRO water vapour retrieval relies on the $940 \mathrm{~nm}$ absorption band and is described by Sioris et al. (2010a) and has been updated recently
(Sioris et al., 2015). The water vapour profiles have $\sim 1 \mathrm{~km}$ vertical resolution (Sioris et al., 2010a). Figures 1-2 present the validation of MAESTRO water vapour. MAESTRO is seen to have less scatter than ACE-FTS below $6.5 \mathrm{~km}$. Between 6.5 and $19.5 \mathrm{~km}$, the median of the relative differences between MAESTRO and ACE-FTS of their individual collocated profiles is $<20 \%$, which is also true only for MIPAS IMK data (Stiller et al., 2012) considering the other UTLS water vapour data products compared in Fig. 2. However, due to the relatively large noise in the MAESTRO lower stratospheric water vapour data (Fig. 2), the scatter in the relative differences between individual coincident ACE-FTS and MAESTRO profiles is of the order of $\sim 35 \%$, whereas those between ACE-FTS and other atmospheric sounders are typically of the order of $\sim 10 \%$ in this region.

Sioris et al. (2010a) found a weak sensitivity of the water vapour retrieval to significant perturbations in aerosol extinction. As discussed in Sioris et al. (2010a), the weaker sensitivity of MAESTRO water vapour to aerosol extinction relative to other solar occultation instruments which have used this absorption band, namely Polar Ozone and Aerosol Measurement (POAM) III and SAGE II, is due to the availability of "off" wavelengths (i.e. with minimal absorption by water vapour) on both sides of the water vapour band, which neither of these other instruments incorporated into their channel selection. This issue is also true for SAGE III (Thomason et al., 2010) with neighbouring channels at 869 and $1021 \mathrm{~nm}$, but to a lesser extent than for SAGE II.

ACE-FTS gridded version 3.5 water vapour profiles are used in the study (Boone et al., 2013) and are assumed to have $3 \mathrm{~km}$ vertical resolution. This data set has been validated as discussed in the companion paper (Sioris et al., 2015). Over the microwindows used to retrieve water vapour from ACE-FTS spectra (Boone et al., 2005), absorption by this trace gas is completely uncorrelated with the spectrally smooth aerosol extinction signature. The insensitivity to aerosol extinction of water vapour retrieved from highresolution solar occultation spectra using microwindows is well known (e.g. Rinsland et al., 1994; Michelsen et al., 2002; Steele et al., 2006; Uemera et al., 2005). The use of a slope term in each microwindow accounts for the smooth aerosol extinction (Boone et al., 2005). Over each microwindow used to retrieve water vapour, no higher-order baseline terms are necessary. The complete insensitivity to aerosol extinction is an advantage of the microwindow technique relative to the band-integrated approach used in the MAESTRO water vapour retrieval. This advantage is possible due to the high spectral resolution of ACE-FTS, which assists in separating the continuum level from the deep absorption lines due to light, gas-phase species such as water vapour.

Based on temperature profiles from the Global Environmental Multiscale (GEM) regional weather forecast model (Laroche et al., 1999), the tropopause height is defined by the lower of the lowest local minimum above $5 \mathrm{~km}$ or the lowest height above $5 \mathrm{~km}$ at which the lapse rate is $<2 \mathrm{~K} \mathrm{~km}^{-1}$. 

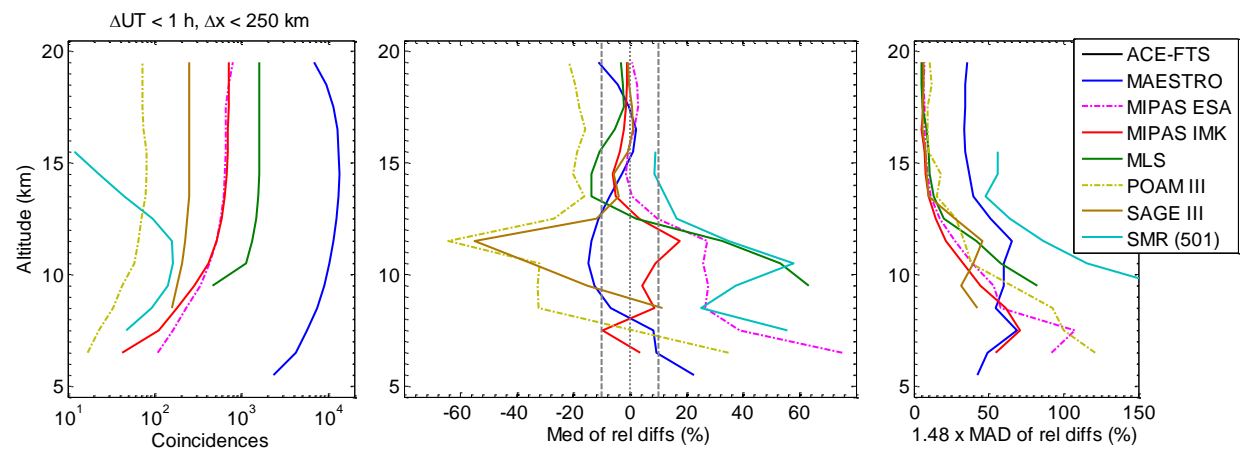

Figure 2. (Left) Number of coincidences globally as a function of altitude between ACE-FTS and various limb sounders that measured water vapour in the ACE time period. The coincidence criteria are $<1 \mathrm{~h}$ in time and within $250 \mathrm{~km}$. (Centre) Median of relative differences in water vapour versus ACE-FTS (the minuend). The profiles from the instrument with the coarser vertical resolution are smoothed to account for the difference in resolution between ACE-FTS and the correlative instrument. ACE-FTS has a coarser vertical resolution than most of the chosen instruments. (Right) Variability of the relative differences. SAGE is the Stratospheric Aerosol and Gas Experiment. MIPAS IMK is the Michelson Interferometer for Passive Atmospheric Sounding water vapour product developed at the Institut für Meteorologie und Klimaforschung (IMK). The MIPAS water vapour product from the European Space Agency (ESA) is also illustrated. SMR is the sub-mm radiometer on Odin, and the Aura MLS (Microwave Limb Sounder) is used.

Further details are given in the companion paper (Sioris et al., 2015).

To obtain a water vapour relative anomaly time series for the UTLS, the method is described by Sioris et al. (2015). The monthly climatology, used to deseasonalize the time series, is generated by averaging the monthly medians over the populated years, with a minimum sample size of 20 observations per altitude bin in each individual month. Between 5.5 and $19.5 \mathrm{~km}$ using $1 \mathrm{~km}$ vertical bins, climatological profiles are obtained for all calendar months except April, June, August, and December at northern high latitudes $\left(60-90^{\circ} \mathrm{N}\right)$ and all months except February, June, October, and December at southern high latitudes $\left(60-90^{\circ} \mathrm{S}\right)$, as ACE does not sample these regions in these months. For the case studies presented next, there are at least 65 profiles measured by MAESTRO and by ACE-FTS for each month in the JulySeptember 2011 period at southern high latitudes (PuyehueCordón Caulle) and in May 2010 at northern high latitudes (Eyjafjallajökull).

\section{Results}

Upper tropospheric time series of water vapour VMR observed by MAESTRO over the full mission to date are shown in Fig. 3. This high-latitude UTWV time series is novel in terms of the spatial coverage only achievable by a satelliteborne instrument, the length of the data record, and the vertical resolution down to the mid-troposphere. Previous studies by Hegglin et al. $(2013,2014)$ provided water vapour time series (2004-2010) from ACE-FTS and other limb sounders for pressures as large as 300 or $100 \mathrm{hPa}$, respectively, with a focus on the stratosphere.

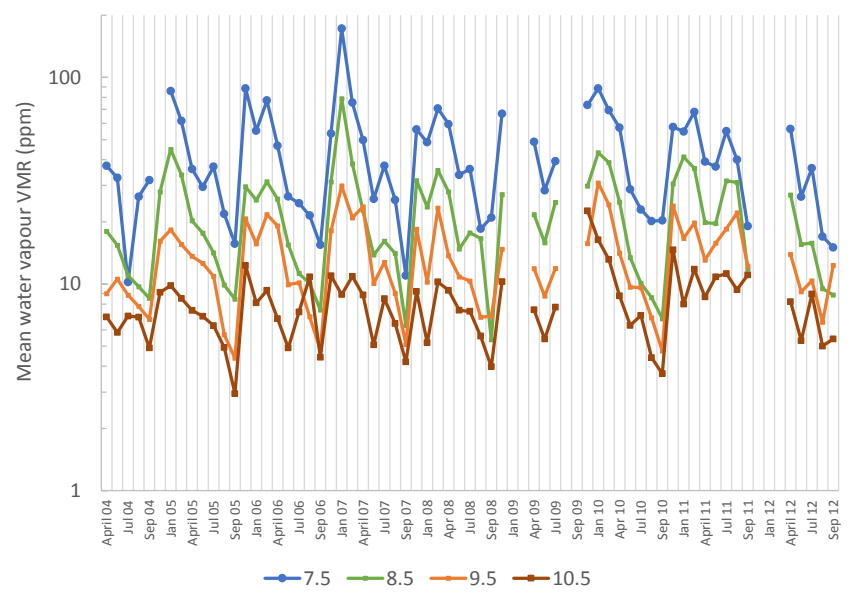

Figure 3. Monthly mean time series of the MAESTRO water vapour mixing ratio at different heights (indicated in legend, in $\mathrm{km}$ ) in the southern high-latitude tropopause region. Months of February, June, October, December are not included as ACE does not sample in this region during those months. Discontinuities indicate insufficient data during the other 8 calendar months. A logarithmic scale is used for the $y$ axis.

\subsection{Puyehue-Cordón Caulle}

The Puyehue-Cordón Caulle volcano $\left(40.59^{\circ} \mathrm{S}, 72.12^{\circ} \mathrm{W}\right)$ erupted explosively in early June of 2011. The volcanic explosivity index (VEI; Newhall and Self, 1982) was 5 (http://www.volcano.si.edu/volcano.cfm?vn=357150). Figure 3 shows MAESTRO time series in the UT region, indicating an anomalous increase in the water vapour mixing ratio in July 2011, increasing relative to May 2011 at 7.5$9.5 \mathrm{~km}$, whereas in a typical year, the mixing ratio can be seen to decrease from May to September as part of the strong sea- 


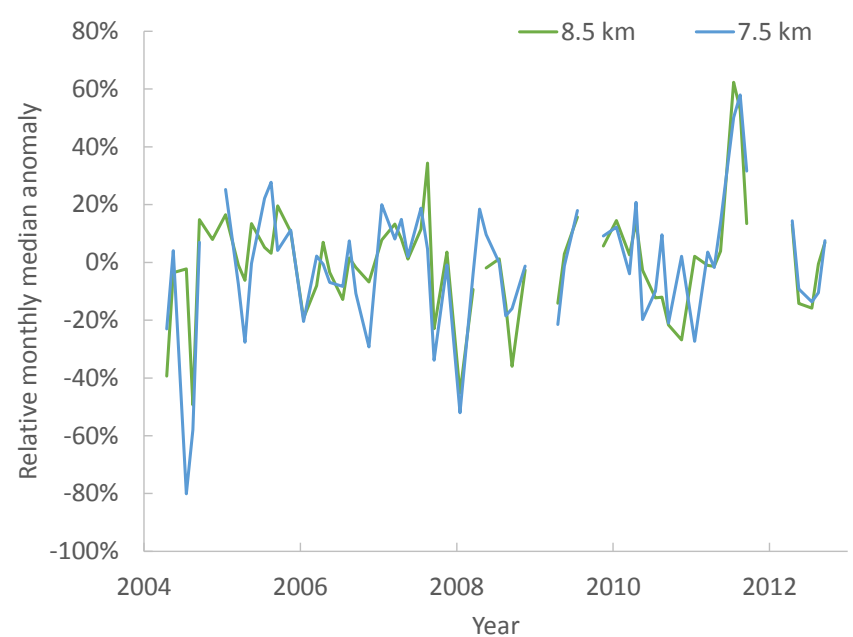

Figure 4. MAESTRO relative monthly median water vapour anomalies at 7.5 and $8.5 \mathrm{~km}$ at southern high latitudes $\left(60-90^{\circ} \mathrm{S}\right)$.

sonal cycle. Note that the upper troposphere is not warmer in July 2011 than in May 2011 according to GEM model analysis temperatures (Laroche et al., 1999) sampled at the locations of ACE observations. In fact, there is a steady, seasonal decrease in temperature at these altitudes, with a drop of $7 \mathrm{~K}$ at $9.5 \mathrm{~km}$ in this time period. Figure 4 is a deseasonalized version of Fig. 3, illustrating a large, sudden increase in high-latitude UTWV in July 2011 that significantly biases (at the $1 \sigma$ level) the inferred decadal trend at $8.5 \mathrm{~km}$.

To connect the clearly enhanced UTWV at southern high latitudes to the eruption of Puyehue-Cordón Caulle (Cordón Caulle hereafter), ACE UTWV profiles in the $40-60^{\circ} \mathrm{S}$ band, which contains the latitude of this volcano, were contrasted between July 2011 and July 2012 (a normal July). Figure 5 shows a statistically significant increase in zonal median UTWV in the $40-60^{\circ} \mathrm{S}$ latitude band as well for July 2011 relative to July 2012 , with a sharp peak at $\sim 8 \mathrm{~km}$ and no significant increase above $11 \mathrm{~km}$ or below $7 \mathrm{~km}$. ACE samples the $40-60^{\circ} \mathrm{S}$ band in the first 12 days of the month and then samples the $60-90^{\circ} \mathrm{S}$ band (actually $60-66^{\circ} \mathrm{S}$ ) for the remainder of the month. Note that the spatiotemporal sampling repeats annually for ACE as illustrated by Randel et al. (2012). The large increase in water vapour at $8 \mathrm{~km}$ in July 2011 is coherent between latitude bands (Fig. 5), providing evidence of the poleward transport of water in the tropopause region emitted by the Cordón Caulle eruption. Previous observational studies (e.g. Theys et al., 2013; Clarisse et al., 2013) indicate that the plume from the eruption of Cordón Caulle reached as far south as $80^{\circ} \mathrm{S}$ while circling the globe.

The anomalous, sharp peak in monthly median aerosol extinction in the southern high-latitude tropopause region observed by MAESTRO (not shown) and ACE-Imager (Fig. 6) confirms Cordón Caulle aerosol observations by other instruments (Vernier et al., 2013; Theys et al., 2014; Nakamae et

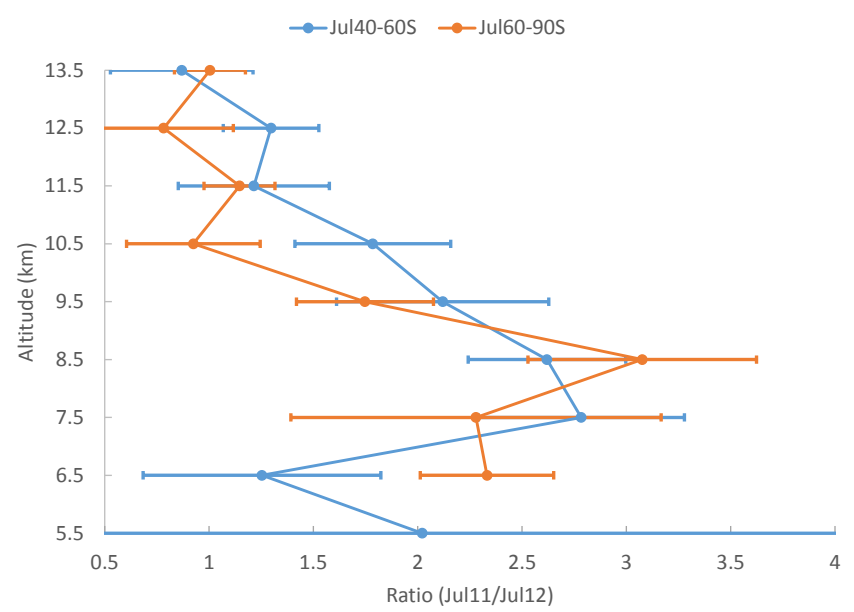

Figure 5. Enhancement factor for the water vapour mixing ratio in July 2011 in the $40-60^{\circ} \mathrm{S}$ band (1-12 July, $N=78$ ) and the 60 $66^{\circ} \mathrm{S}$ band (13-31 July, $N=181$ ), relative to July 2012 . The error bars on the ratio profiles account for 1 standard error of the MAESTRO monthly mean for both years, combined in quadrature.

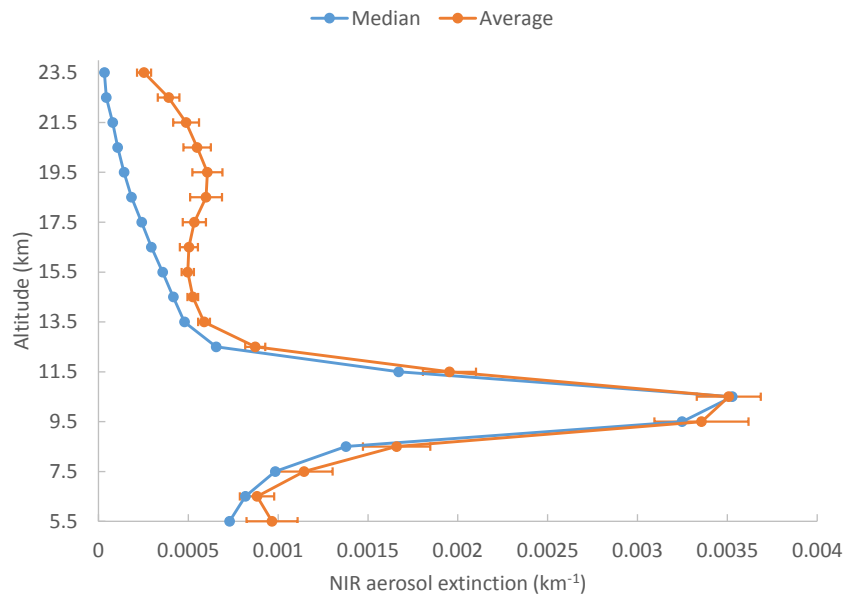

Figure 6. ACE-Imager median and average near-infrared (NIR, $1.02 \mu \mathrm{m})$ aerosol extinction profiles for July 2011 at southern high latitudes $(N=163)$. The error bar is \pm 1 standard error of the monthly mean. The tropopause for this month and latitude band is typically at $9.5 \mathrm{~km}$.

al., 2014) and corroborates the volcanic origin of the water vapour enhancement. In Fig. 6, the median and the mean aerosol extinction in the tropopause region are nearly equal because the Cordón Caulle aerosol layer has spread across all longitudes by July 2011 (Vernier et al., 2013; Clarisse et al., 2013).

The southern high-latitude upper troposphere can be quite cold in austral winter and local condensation is known to occur (Randel et al., 2012). However, the widespread layer in Fig. 6 is unlikely to be due to homogeneously nucleated cirrus given that the monthly median relative humidity $(\mathrm{RH})$ in 1 July 2011 is only $\sim 60 \%$ at the peak (Fig. 7). RH pro- 


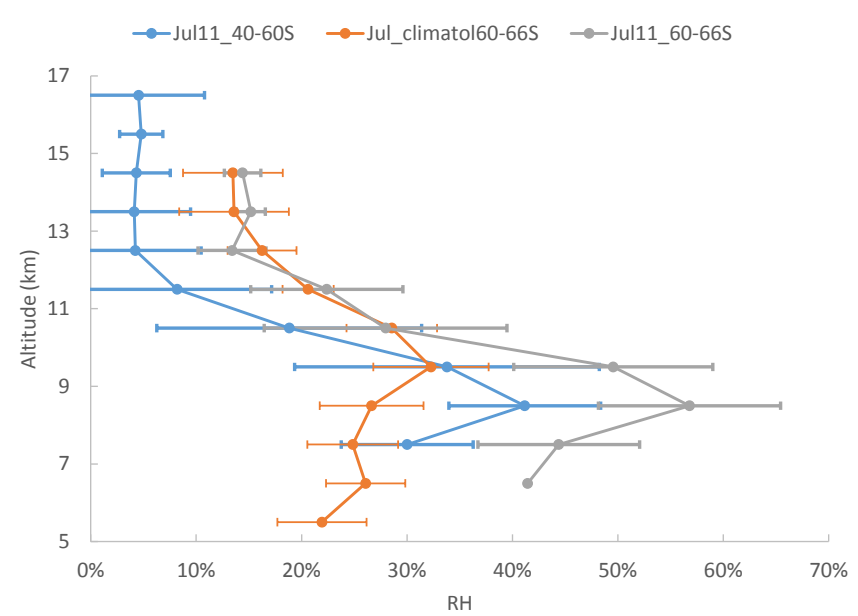

Figure 7. Relative humidity for July $2011\left(40-60^{\circ} \mathrm{S}, N=52\right.$, and $\left.60-66^{\circ} \mathrm{S}, N=111\right)$ and climatology $\left(60-66^{\circ} \mathrm{S}\right.$, July for every year, except 2011 between 6.5 and $9.5 \mathrm{~km}, N=865$ ) determined from MAESTRO water vapour and co-located GEM analysis temperature and pressure (Laroche et al., 1999). The uncertainty on the climatologic RH accounts for interannual variability in water vapour and saturated water vapour mixing ratio, combined in quadrature. The error bars in the July $2011 \mathrm{RH}$ profiles only account for the standard error of the monthly mean water vapour.

files (Fig. 7) are used to emphasize that most of the volcanic water vapour enhancement will tend to remain in the vapour phase as it resides in the southern high-latitude upper troposphere. At southern mid-latitudes $\left(40-60^{\circ} \mathrm{S}\right)$, the earliest available ACE-Imager aerosol extinction profile observations (i.e. early July 2011) indicate a fine plume peaking at $9.5 \mathrm{~km}$ (not shown). Relative humidity in the $40-60^{\circ} \mathrm{S}$ band obtained using MAESTRO water vapour peaks at $41 \pm 14 \%$ at $8.5 \mathrm{~km}$ (Fig. 7), establishing that the upper troposphere in this mid-latitude band was not saturated 1 month after the eruption. Both the mid-latitude and high-latitude $\mathrm{RH}$ profiles in July 2011 peak at $8.5 \mathrm{~km}$, with slightly higher relative humidity at high latitudes where the volcanic UTWV enhancement encountered cooler ambient air at altitudes between 7.5 and $9.5 \mathrm{~km}$.

Considering both the ACE-FTS (Bernath et al., 2005) and MAESTRO measurements, the largest relative enhancements in water vapour in July 2011 occur at $7.5-9.5 \mathrm{~km}$, where a doubling is observed relative to normal mixing ratios for that month (see Fig. 8). In August 2011, the relative anomaly remains of similar magnitude throughout the upper troposphere, and is statistically significant $(1 \sigma)$ at $7.5-8.5 \mathrm{~km}$ (seen by both instruments), whereas in September 2011, the UTWV enhancement is statistically insignificant. Part of the August 2011 enhancement may be unrelated to the volcanic eruption since there is an unusual warming of $\sim 3 \mathrm{~K}$ at 7.5 and $8.5 \mathrm{~km}$, the largest positive anomaly in the entire southern high-latitude temperature record (2004-2012) at these altitudes. This enhancement is unlikely to be a radiative feed-

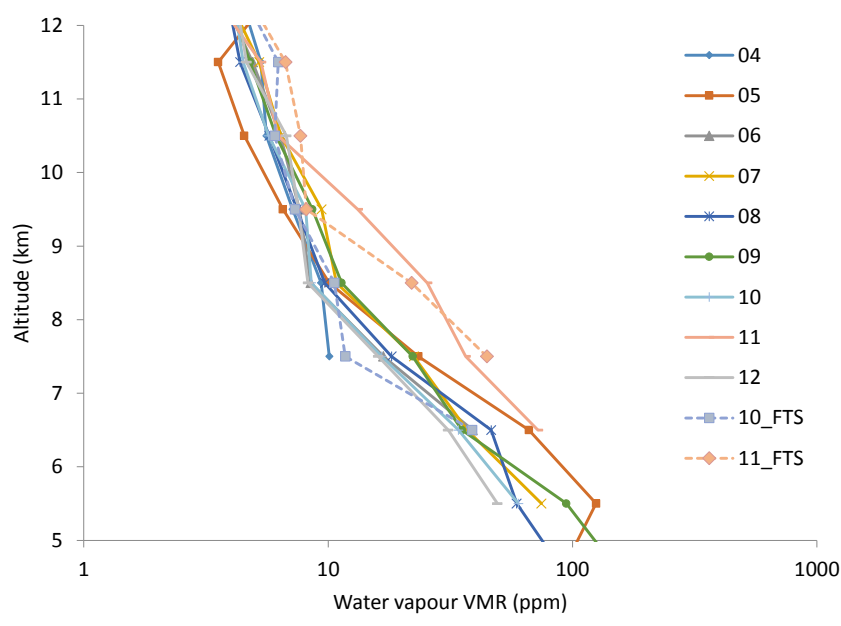

Figure 8. Southern high-latitude $\left(60-90^{\circ} \mathrm{S}\right)$ monthly median water vapour profiles in July for different years. MAESTRO: 2004 2012; ACE-FTS: $2010(N=169)$ and $2011(N=176)$. A logarithmic scale is used for the $x$ axis. The number of July profiles (60$90^{\circ} \mathrm{S}$ ) for MAESTRO is 96 per year on average.

back of volcanically enhanced UTWV since the July 2011 temperatures are within $+0.4 \mathrm{~K}$ of the July climatology. The observed decrease over these austral winter months is consistent with the lifetime of water vapour in the upper troposphere (Ehhalt, 1973; Grewe and Stenke, 2008) within measurement uncertainties. In July 2011, relative humidity of $100 \%$ with respect to ice (see Murray, 1967) was reached in some profile observations in the southern high-latitude upper troposphere, with the corresponding MAESTRO aerosol extinction observations indicating a vertically thin plume of fine particles. Thus, ice-coated tropospheric aerosols are inferred to be present for these cases.

\subsection{Eyjafjallajökull}

Eyjafjallajökull $\left(63.63^{\circ} \mathrm{N}, 19.62^{\circ} \mathrm{E}\right)$ began erupting on 14 April 2010 beneath $210 \mathrm{~m}$ of glacial ice (Magnússon et al., 2012), reaching an altitude of $10 \mathrm{~km}$ (Gudmundsson et al., 2012). This was followed by a second eruption on 5 May 2010 that also reached $\sim 10.0 \mathrm{~km}$ (Gudmundsson et al., 2012). ACE does not cover northern high latitudes in April, but in May 2010, MAESTRO and ACE-FTS both see statistically significant enhancements in water vapour at 8.5 $9.5 \mathrm{~km}$ (Fig. 9). In fact, at $9.5 \mathrm{~km}$, the $(69 \pm 10) \%$ anomaly in May 2010 is the largest anomaly at this altitude in any of the 63 months that sample northern high latitudes in either data set. The stated statistical significance accounts for the interannual variability for the month of May and the relative standard error for May 2010 for each data set, respectively. The monthly mean tropopause height in May 2010 is $10.5 \mathrm{~km}$, but some individual observations have a tropopause height as high as $11.5 \mathrm{~km}$. The peak of the Eyjafjallajökull aerosol layer is at $7.5 \mathrm{~km}$ approximately 1 month after eruption 


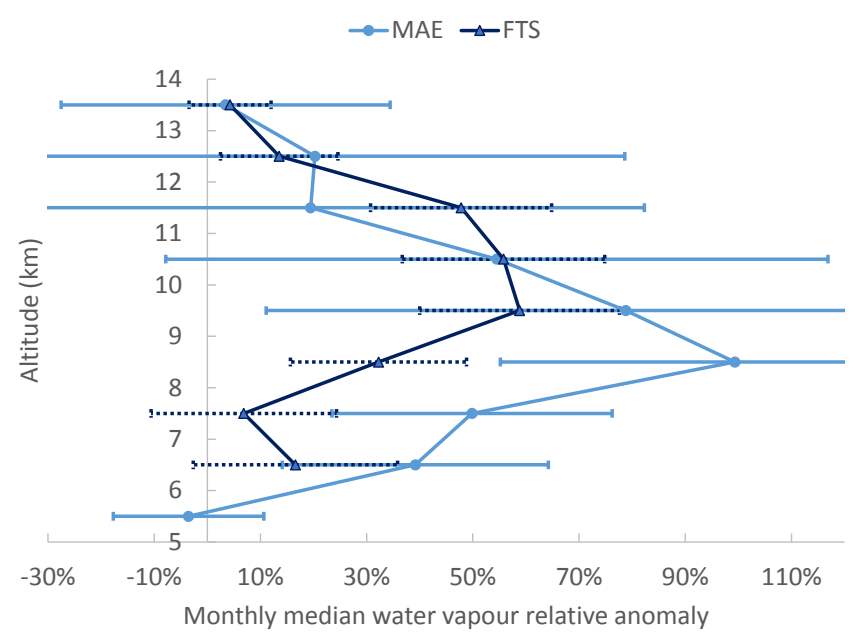

Figure 9. Water vapour relative anomaly in May 2010 at northern high latitudes following the Eyjafjallajökull eruption. The uncertainty accounts for the interannual standard deviation for May (2005-2012) and the relative standard error of individual profiles from the month of May 2010, combined in quadrature $(N=132$, 178 for MAESTRO and ACE-FTS, respectively).

(Fig. 10). Figure 10 reveals an upper tropospheric aerosol layer that is not homogeneously spread throughout northern high latitudes based on differences between MAESTRO $560 \mathrm{~nm}$ May 2010 mean and median aerosol extinction profiles and the fact that both peak at $7.5 \mathrm{~km}$. The ACE-Imager NIR data at northern high latitudes in May 2010 confirm an aerosol layer at $7.5 \pm 0.5 \mathrm{~km}$ (not shown). The Arctic oscillation would be expected to increase water vapour by $<8 \%$ at $8.5-9.5 \mathrm{~km}$ in May 2010 according to the regression using year-round monthly sampled data as determined in the companion paper (Sioris et al., 2015), and is thus insufficient to explain the increase. Also, although dehydrated and rehydrated layers were observed in the 2010 winter (Khaykin et al., 2013), water vapour in the upper troposphere and lower stratosphere (UTLS, 5-20 km) in the northern high-latitude region in March 2010 was normal according to both MAESTRO and ACE-FTS. ACE does not sample northern high latitudes in June. In July 2010, enhanced UTWV is observed by both instruments only at the local tropopause $(11.5 \mathrm{~km})$, but for MAESTRO, this enhancement is not statistically significant.

\section{Discussion}

In the time span of 14 months (April 2010 to June 2011), two extratropical eruptions with $\mathrm{VEI} \geq 4$ occurred that were followed by significantly enhanced UTWV at high latitudes in the hemisphere of the eruption. Monthly median UTWV VMR increases of up to $50 \%$ were observed and the duration of each volcanic enhancement was $\sim 1$ month. While both of these eruptions impacted the high-latitude upper troposphere in the hemisphere of the eruption, one of these volcanoes, namely Cordón Caulle, is located at southern mid-latitudes.

During poleward transport, air parcels follow isentropes typically to higher altitudes. Such transport involves adiabatic cooling which can lead to saturation. However, saturation does not necessarily imply complete removal from the atmosphere or even the upper troposphere. The small ice crystals that typically form in the upper troposphere (e.g. Wang, 2008) would likely evaporate before falling (Prospero et al., 1983), but if growth in size were sufficient for fallout, vaporization could occur very quickly given the warmer temperatures below. Thus, the large majority of water would tend to remain in the vapour phase and in the upper troposphere during poleward transport on an upward sloping isentrope in surrounding dry air (see Fig. 7).

Next, relying heavily on several previous observational and theoretical studies, we attempt to estimate the mass of water vapour attributable to each volcanic eruption using a bottom-up approach and compare this to the "top-down" UTWV mass anomaly derived from the satellite observations. In general, magmatic water and entrained lower tropospheric humidity are the two volcanogenic sources of UTWV (Glaze et al., 1997; Durant and Rose, 2009). For Eyjafjallajökull, a third significant source of UTWV is from the vaporization of ice over the vents which would be carried up in the eruption column. According to Sigmundsson et al. (2010), the interaction of ice and magma initially augmented the explosive activity of the Eyjafjallajökull eruption.

The estimate of magmatic water mass is based on the petrographic method (e.g. Durant and Rose, 2009). An alternative method based on the ratio of water vapour to $\mathrm{SO}_{2}$ and the known mass of emitted $\mathrm{SO}_{2}$ would give a low bias for the magmatic water mass for these two studied eruptions because the emitted mass of $\mathrm{SO}_{2}$ from these eruptions was unusually low (Pumphrey et al., 2015; Vernier et al., 2013; Nakamae et al., 2014; Sears et al., 2013). Volcanic emissions are known to be more variable in terms of $\mathrm{SO}_{2}$ than water vapour (Pinto et al., 1989). Following Durant and Rose (2009), the mass of magmatic water vapour $\left(M_{\mathrm{v}, \mathrm{m}}\right)$ is the product of the total erupted mass and the mass fraction of water vapour in magma. The latter factor is assumed to be $6 \%$ for both Cordón Caulle and Eyjafjallajökull, which is within 1 standard deviation $(1.6 \%)$ of the Eyjafjallajökull mean value of $4.6 \%$ (Table 6 of Woodhouse et al., 2013, assuming $80 \%$ water vapour based on Pinto et al., 1989) and within the typical range of 4-6\% (Grove et al., 2009). The total erupted mass for Cordón Caulle is determined by multiplying a total erupted volume of $1.9 \mathrm{~km}^{3}$ (Dr. Elizabeth Cottrelle, Global Volcanism Program, Smithsonian Institution, personal communication, 2015) by an ash density of $2300 \mathrm{~kg} \mathrm{~m}^{-3}$ appropriate for glass, since most of the erupted mass was glass (Bertrand et al., 2014). Bonadonna et al. (2015) estimated the total erupted volume to be $1.1 \pm 0.2 \mathrm{~km}^{3}$, while Bertrand et al. (2014) imply $>3 \mathrm{~km}^{3}$. The total erupted mass for Eyjafjallajökull is $480 \pm 120 \mathrm{Mt}$ (Gudmundsson et al., 2012). The 
mass of entrained lower tropospheric water vapour $\left(M_{\mathrm{v}, \mathrm{e}}\right)$ consists of the radial and wind entrainment terms (Degruyter and Bonadonna, 2012). The total mass of water vapour $\left(M_{\mathrm{v}, \mathrm{t}}\right)$ is, in general, given by

$M_{\mathrm{v}, \mathrm{t}}=M_{\mathrm{v}, \mathrm{m}}+M_{\mathrm{v}, \mathrm{e}}$.

Eyjafjallajökull (Schmidt et al., 2014) and Cordón Caulle (http://volcano.si.edu/volcano.cfm?vn=357150\#June2011) were different from many recent extratropical volcanic eruptions with VEI of 4 such as Grímsvötn, Kasatochi, and Sarychev Peak in that, for both volcanoes studied here, the eruptive phase spanned more than 5 weeks with an eruption height of $7 \mathrm{~km}$ above sea level attained on several $(\geq 5)$ days during this time period. The mass flux rate remained less than $0.017 \mathrm{Mts}^{-1}$ during the entire eruptive phase for both studied volcanoes (Gudmundsson et al., 2012; Bonadonna et al., 2015), and thus all of the repeated eruptions were considered "smaller", meaning that Table 2 of Glaze et al. (1997) would be applicable to determine radial entrainment of tropospheric water vapour. Eyjafjallajökull is assumed to have erupted through a wet atmosphere based on Fig. S5 of Degruyter and Bonadonna (2012) with moderate condensation (2\%, Glaze et al., 1997), and Cordón Caulle is assumed to have erupted through a dry atmosphere with moderate condensation. To include the wind entrainment term, the mass of radially entrained tropospheric water vapour is scaled by $1+1 / \Pi$, where $\Pi$ is the scaling parameter of Degruyter and Bonadonna (2012). This increases the entrained mass by a factor of 11 and 6.6 for Cordón Caulle and Eyjafjallajökull, respectively, as both erupted under windy conditions (Bonadonna et al., 2015; Petersen et al., 2012) and were observed as bent-over plumes, whereas Grímsvötn erupted during low wind speed conditions, and consequently wind entrainment was a minor factor (Woodhouse et al., 2015). The $\Pi$ value for Cordón Caulle is appropriate for the early part of its eruptive phase (5-14 June 2011) when most of the mass of volcanic material erupted (Fig. 6 of Bonadonna et al., 2015), and for Eyjafjallajökull, the maximum $\Pi$ value of 0.18 is conservatively assumed (Degruyter and Bonadonna, 2012).

For Eyjafjallajökull, there is the additional contribution by the vaporization of the glacial ice covering the three active vents. Each vent is assumed to have a $150 \mathrm{~m}$ radius (upper limit based on Bursik et al., 2012) and have $200 \mathrm{~m}$ of overlying ice (Magnússon et al., 2012) that instantaneously vaporized and was carried upward within the eruption column. A much larger mass of ice in the surrounding area melted or vaporized during the eruptive phase (Gudmundsson et al., 2012), but it was assumed that this did not affect the upper troposphere. Table 1 provides estimates of the contributions by ice vaporization, wind and radial entrainment, and magmatic water as well as key inputs.

The observed UTWV anomaly is converted to a mass by assuming a latitude range (Table 1) over which the zonal median water vapour VMR enhancement profile is assumed to

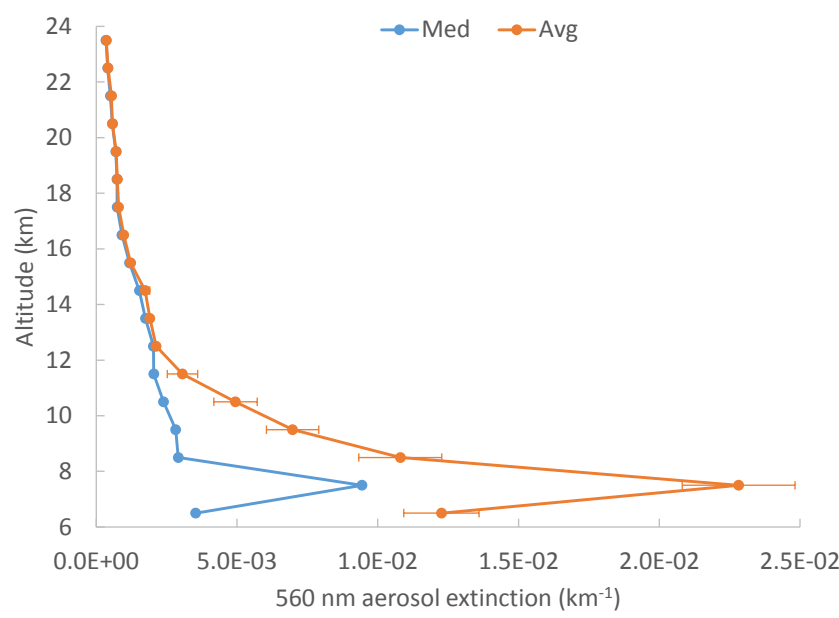

Figure 10. Median and average aerosol extinction observed by MAESTRO at $560 \mathrm{~nm}$ in May 2010 at northern high latitudes $(N=$ 167).

be latitude-independent. For Cordón Caulle, the plume is assumed to span $50-80^{\circ} \mathrm{S}$ based on Theys et al. (2013). For Eyjafjallajökull, several studies show that a reasonable latitude band for the plume is $50-70^{\circ} \mathrm{N}$ (e.g. Gudmundsson et al., 2012; Clarisse et al., 2010; Schmidt et al., 2014; Schumann et al., 2011; Sears et al., 2013; Thomas and Prata, 2011).

The water vapour mass anomaly calculation also requires integration over the altitude range for which ACE sensors detect a significant positive anomaly during the calendar month following the initial eruption: $8.0-10.0 \mathrm{~km}$ in May 2010 for Eyjafjallajökull and 6.0-10.0 km in July 2011 for Cordón Caulle (although only MAESTRO has a sufficient sample size between 6.0 and $7.0 \mathrm{~km}$ for the latter month). The smaller of the MAESTRO and ACE-FTS water vapour anomalies is used at each $1 \mathrm{~km}$ vertical level within these altitude ranges.

The anomaly is adjusted for the altitude-dependent response of the local annular mode (AM) using Figs. 89 of Sioris et al. (2015) and monthly AM indices (http: //www.cpc.noaa.gov/products/precip/CWlink/). This adjustment is applied over the assumed latitude range of the anomaly (Table 1), even though the response was determined for latitudes poleward of $60^{\circ}$. Finally, the $\sim 1$ month residence of water vapour in the high-latitude upper troposphere (Grewe and Stenke, 2008) is taken into account using an exponential decay. For Cordón Caulle, eruption heights (http://volcano.si.edu/volcano.cfm?vn=357150\# June2011) and HYSPLIT (Stein et al., 2015) forward trajectories (not shown) are used to determine, for each of several eruptions reaching the upper troposphere, whether volcanic material at the top of the eruption column maintained its altitude and headed south of $50^{\circ} \mathrm{S}$ during the four subsequent days. On this basis, the latest eruptions are rejected as likely contributors to the observed UTWV anomaly and, thus, re- 
Table 1. Inputs and outputs of volcanic water vapour mass derived from bottom-up and top-down approaches.

\begin{tabular}{lll}
\hline Quantity & Cordón Caulle & Eyjafjallajökull \\
\hline Total erupted mass (Mt) & 4400 & 480 \\
Mass of magmatic water vapour (Mt) & 300 & 30 \\
Mass of water vapour entrained radially (Mt) & 100 & 70 \\
Mass of water vapour entrained by wind (Mt) & 900 & 400 \\
Mass of water vapour from vaporized ice (Mt) & 0 & 40 \\
Lower tropospheric humidity & Dry & Wet \\
Extent of condensation & Moderate & Moderate \\
Latitude band of observed UTWV mass anomaly & $50-80^{\circ} \mathrm{S}$ & $50-70^{\circ} \mathrm{N}$ \\
Vertical range of significant UTWV anomaly & $6.0-10.0 \mathrm{~km}$ & $8.0-10.0 \mathrm{~km}$ \\
Month of observed UTWV mass anomaly & July 2011 & May 2010 \\
Annular mode index in this month & AAO index: -1.38 & AO index: -0.919 \\
UTWV mass anomaly (Mt) at time of volcanic injection, adjusting for annular mode response & 1000 & 500 \\
\hline
\end{tabular}

moval is taken into account using 13 June and 18 July 2011 as the start date of the exponential decay in the 8.0-10.0 and $6.0-8.0 \mathrm{~km}$ ranges, respectively. By accounting for the residence time, the observed mass anomaly at the start date is derived and can be directly compared to the bottom-up mass estimate. A mass of $1000 \mathrm{Mt}$ is derived for Cordón Caulle, in good agreement with the combined mass from entrainment terms and magmatic water (Table 1).

For Eyjafjallajökull, the total erupted mass removal is assumed to be altitude-independent, and a period of 18.5 days is used, meaning that the eruption on 5 May 2010 reaching an altitude of $10 \mathrm{~km}$ (e.g. Gudmundsson et al., 2012) is assumed to contribute significantly. An initial mass of $500 \mathrm{Mt}$ of water vapour is derived from the ACE observations, which is also in agreement with the estimated contributions by magmatic water, entrainment, and vaporized ice (Table 1). The uncertainties in both the bottom-up and top-down estimates are large in number and magnitude.

Bearing in mind previous work that considered the effect of water vapour in the tropical tropopause region on the overall radiation balance of the troposphere (e.g. Solomon et al., 2010), cooling rate calculations were performed to determine the impact on the temperature at the Antarctic surface (see Appendix A for details of the method). The large enhancement in UTWV at southern high latitudes in July 2011 leads to a cooling rate difference of $-0.003 \mathrm{~K} \mathrm{day}^{-1}$ at the surface, which is equivalent to a warming of $0.1 \mathrm{~K}$ per month.

As noted above, considering the VEI values of 4 and 5 for Eyjafjallajökull and Cordón Caulle, respectively, their $\mathrm{SO}_{2}$ emissions were small, thereby reducing the probability of water uptake by the resulting sulfate aerosol. However, this is a minor factor in understanding the large anomaly in UTWV in May 2010 relative to wind entrainment. Besides the eruption of Eyjafjallajökull, the only high-latitude eruption with VEI of 4 during the ACE time frame is Grímsvötn in late May of 2011 and would be the most likely to enhance UTWV at high latitudes. Unfortunately, ACE did not measure at north- ern high latitudes in June 2011, the month which would be most likely to be perturbed in terms of UTWV.

\section{Conclusions}

Due to the sporadic nature of volcanic eruptions, the UTWV variability explained by these short-lived perturbations at high latitudes over decadal timescales is much less than is attributable to the relevant annular mode of internal variability. However, this study shows that volcanic eruptions can lead to UTWV increases on a monthly timescale of $\sim 50 \%$, comparable to the UTWV increases observed during the largest annular mode negative events (Sioris et al., 2015). While the climatic impact of enhanced water vapour due to the Cordón Caulle eruption is shown to be minor, particularly given the short period of this volcanic enhancement, such increases are relevant for UTWV trend studies, particularly if an eruption occurs near the start or end of the period under consideration.

Volcanic UTWV enhancements in the extratropics during the cold season are more readily detected in monthly zonal median data because of the low background VMR of water vapour in this region and season. Thus, the timing and location of the Cordón Caulle eruption were favourable for detecting its water vapour enhancement at southern high latitudes. In contrast, the six extratropical eruptions with a VEI of 4 in the 2004-2013 time frame occurred in late spring (e.g. Sarychev Peak), summer (Kasatochi, Okmok), or early autumn (Chaitén).

Entrainment of lower tropospheric humidity by windblown plumes is critical in explaining the observed UTWV mass anomalies generated by the two studied eruptions. The available wind entrainment information is consistent with the observed UTWV enhancements. Furthermore, the wind has a major role in limiting the eruption height (e.g. Bonadonna et al., 2015), thereby confining more of the emitted and entrained water vapour in the upper troposphere. The height of the eruption column for Cordón Caulle was anomalously low for an eruption with VEI of 5 (Table 1 of Newhall and Self, 
1982), and this discrepancy can be largely explained by the strong winds (Bonadonna et al., 2015) and the duration of the eruptive phase. Using Eq. (3) of Bonadonna et al. (2015) and a $\Pi$ value of 0.18 (Degruyter and Bonadonna, 2012; see Sect. 4 above), it is concluded that the height of the eruption column for Eyjafjallajökull was also limited to the upper troposphere because of strong winds.
Finally, MAESTRO, a solar occultation instrument operating at visible and near-infrared wavelengths, has the unique capability among current space-borne instruments to simultaneously observe vertical profiles of aerosol extinction and water vapour in the UTLS to provide an understanding of the impact of volcanic eruptions on the water vapour budget and trends in water vapour. 


\section{Appendix A: Cooling rate differences}

In order to investigate the impact on volcanic UTWV enhancements on surface temperature, cooling rate vertical profiles are calculated for July 2011 using MODTRAN5.2 (e.g. Bernstein et al., 1996) assuming an Antarctic surface altitude of $2.5 \mathrm{~km}$, the tropospheric monthly median profile of the GEM analysis temperatures (to the surface), aerosol extinction profiles from MAESTRO at $560 \mathrm{~nm}$ down to $5 \mathrm{~km}$, and two water vapour cases

1. using MAESTRO July climatological median water vapour between 6.5 and $9.5 \mathrm{~km}$, and

2. with the increase in water vapour over this altitude range due to the Cordón Caulle eruption determined by multiple linear regression with the Antarctic oscillation index (Mo, 2000) (http://www.cpc.ncep.noaa. gov/products/precip/CWlink/) plus a constant being the other basis functions. A monthly time step is used with the Cordón Caulle eruption basis function having a value of 1 for July-August 2011 and 0 in all other months for the purpose of the regression analysis.

The use of a multiple linear regression adjusts for a minor contribution by the Antarctic oscillation to the July 2011 UTWV enhancement. 
Acknowledgements. The ACE mission is supported primarily by the Canadian Space Agency. David Plummer (Environment and Climate Change Canada) is acknowledged for his encouragement to perform cooling rate simulations for the Cordón Caulle eruption. The authors appreciate the availability of the AO and AAO indices from the National Oceanic and Atmospheric Administration (NOAA). The authors gratefully acknowledge the NOAA Air Resources Laboratory for the provision of the HYSPLIT transport and dispersion model used in this publication.

Edited by: T. von Clarmann

\section{References}

Bernath, P. F., McElroy, C. T., Abrams, M. C., Boone, C. D., Butler, M., Camy-Peyret, C., Carleer, M., Clerbaux, C., Coheur, P.-F., Colin, R., DeCola, P., DeMazière, M., Drummond, J. R., Dufour, D., Evans, W. F. J., Fast, H., Fussen, D., Gilbert, K., Jennings, D. E., Llewellyn, E. J., Lowe, R. P., Mahieu, E., McConnell, J. C., McHugh, M., McLeod, S. D., Michaud, R., Midwinter, C., Nassar, R., Nichitiu, F., Nowlan, C., Rinsland, C. P., Rochon, Y. J., Rowlands, N., Semeniuk, K., Simon, P., Skelton, R., Sloan, J. J., Soucy, M.-A., Strong, K., Tremblay, P., Turnbull, D., Walker, K. A., Walkty, I., Wardle, D. A., Wehrle, V., Zander, R., and Zou, J.: Atmospheric Chemistry Experiment (ACE): mission overview, Geophys. Res. Lett., 32, L15S01, doi:10.1029/2005GL022386, 2005.

Bernstein, L. S., Berk, A., Acharya, P. K., Robertson, D. C., Anderson, G. P., Chetwynd, J. H., and Kimball, L. M.: Very narrow band model calculations of atmospheric fluxes and cooling rates, J. Atmos. Sci., 53, 2887-2904, 1996.

Bertrand, S., Daga, R., Bedert, R., and Fontijn, K.: Deposition of the 2011-2012 Cordón Caulle tephra (Chile, $40^{\circ} \mathrm{S}$ ) in lake sediments: Implications for tephrochronology and volcanology, J. Geophys. Res.-Earth, 119, 2555-2573, doi:10.1002/2014JF003321, 2014.

Bonadonna, C., Pistolesi, M., Cioni, R., Degruyter, W., Elissondo, M., and Baumann, V.: Dynamics of wind-affected volcanic plumes: The example of the 2011 Cordón Caulle eruption, Chile, J. Geophys. Res.-Sol. Ea., 120, 2242-2261, doi:10.1002/2014JB011478, 2015.

Boone, C. D., Nassar, R., Walker, K. A., Rochon, Y., McLeod, S. D., Rinsland, C. P., and Bernath, P. F.: Retrievals for the atmospheric chemistry experiment Fourier-transform spectrometer, Appl. Opt., 44, 7218-7231, 2005.

Boone, C. D., Walker, K. A., and Bernath, P. F.: Version 3 retrievals for the Atmospheric Chemistry Experiment Fourier Transform Spectrometer (ACE-FTS), The Atmospheric Chemistry Experiment ACE at 10: A Solar Occultation Anthology, Deepak Publishing, Hampton, VA, USA, 2013.

Bursik, M., Jones, M., Carn, S., Dean, K., Patra, A., Pavolonis, M., Pitman, E. B., Singh, T., Singla, P., Webley, P., Bjornsson, H., and Ripepe, M.: Estimation and propagation of volcanic source parameter uncertainty in an ash transport and dispersal model: application to the Eyjafjallajokull plume of 14-16 April 2010, Bull. Volcanol., 74, 2321-2338, 2012.

Clarisse, L., Prata, F., Lacour, J.-L., Hurtmans, D., Clerbaux, C., and Coheur, P.-F.: A correlation method for volcanic ash detection using hyperspectral infrared measurements, Geophys. Res. Lett., 37, L19806, doi:10.1029/2010GL044828, 2010.

Clarisse, L., Coheur, P.-F., Prata, F., Hadji-Lazaro, J., Hurtmans, D., and Clerbaux, C.: A unified approach to infrared aerosol remote sensing and type specification, Atmos. Chem. Phys., 13, 21952221, doi:10.5194/acp-13-2195-2013, 2013.

Degruyter, W. and Bonadonna, C.: Improving on mass flow rate estimates of volcanic eruptions, Geophys. Res. Lett., 39, L16308, doi:10.1029/2012GL052566, 2012.

Durant, A. J. and Rose, W. I.: Sedimentological constraints on hydrometeor-enhanced particle deposition: 1992 eruptions of Crater Peak, Alaska, J. Volcanol. Geothermal Res., 186, 40-59, 2009.

Ehhalt, D. H.: Turnover times of ${ }^{137} \mathrm{Cs}$ and HTO in the troposphere and removal rates of natural aerosol particles and water vapour, J. Geophys. Res., 78, 7076-7086, 1973.

Forster, P. M. de F. and Collins, M.: Quantifying the water vapour feedback associated with post-Pinatubo global cooling, Clim. Dynam., 23, 207-214, 2004.

Glaze, L. S., Baloga, S. M., and Wilson, L.: Transport of atmospheric water vapor by volcanic eruption columns, J. Geophys. Res., 102, 6099-6108, 1997.

Grewe, V. and Stenke, A.: AirClim: an efficient tool for climate evaluation of aircraft technology, Atmos. Chem. Phys., 8, 46214639, doi:10.5194/acp-8-4621-2008, 2008.

Grove, T. L., Till, C. B., Lev, E., Chatterjee, N., and Médard, E.: Kinematic variables and water transport control the formation and location of arc volcanoes, Nature, 459, 694-697, 2009.

Gudmundsson, M. T., Thordarson, T., Höskuldsson, Á., Larsen, G., Björnsson, H., Prata, F. J., Oddsson, B., Magnússon, E., Högnadóttir, T., Petersen, G. N., Hayward, C. L., Stevenson, J. A., and Jónsdóttir, I.: Ash generation and distribution from the AprilMay 2010 eruption of Eyjafjallajökull, Iceland, Sci. Rep., 2, 572, doi:10.1038/srep00572, 2012.

Hartmann, D. L., Klein Tank, A. M. G., Rusticucci, M., Alexander, L. V., Brönnimann, S., Charabi, Y., Dentener, F. J., Dlugokencky, E. J., Easterling, D. R., Kaplan, A., Soden, B. J., Thorne, P. W., Wild, M., and Zhai, P. M.: Observations: Atmosphere and Surface, in: Climate Change 2013: The Physical Science Basis, Contribution of Working Group I to the Fifth Assessment Report of the Intergovernmental Panel on Climate Change, edited by: Stocker, T. F., Qin, D., Plattner, G.-K., Tignor, M., Allen, S. K., Boschung, J., Nauels, A., Xia, Y., Bex, V., and Midgley, P. M., Cambridge University Press, Cambridge, United Kingdom and New York, NY, USA, 2013.

Hegglin, M. I., Tegtmeier, S., Anderson, J., Froidevaux, L., Fuller, R., Funke, B., Jones, A., Lingenfelser, G., Lumpe, J., Pendlebury, D., Remsberg, E., Rozanov, A., Toohey, M., Urban, J., von Clarmann, T., Walker, K. A., Wang, R., and Weigel, K.: SPARC Data Initiative: Comparison of water vapor climatologies from international satellite limb sounders, J. Geophys. Res. Atmos., 118, 11824-11846, doi:10.1002/jgrd.50752, 2013.

Hegglin, M. I., Plummer, D. A., Shepherd, T. G., Scinocca, J. F., Anderson, J., Froidevaux, L., Funke, B., Hurst, D., Rozanov, A., Urban, J., von Clarmann, T., Walker, K. A., Wang, H. J., Tegtmeier, S., and Weigel, K.: Vertical structure of stratospheric water vapour trends derived from merged satellite data, Nat. Geosci., 7, 768-776, 2014. 
Junge, C. E.: Air chemistry and radioactivity, Academic Press, New York, 1963.

Khaykin, S. M., Engel, I., Vömel, H., Formanyuk, I. M., Kivi, R., Korshunov, L. I., Krämer, M., Lykov, A. D., Meier, S., Naebert, T., Pitts, M. C., Santee, M. L., Spelten, N., Wienhold, F. G., Yushkov, V. A., and Peter, T.: Arctic stratospheric dehydration - Part 1: Unprecedented observation of vertical redistribution of water, Atmos. Chem. Phys., 13, 11503-11517, doi:10.5194/acp13-11503-2013, 2013.

Laroche, S., Gauthier, P., St-James, J., and Morneau, J.: Implementation of a 3D variational data assimilation system at the Canadian Meteorological Centre. Part II: The regional analysis, Atmos. Ocean, 37, 281-307, 1999.

Magnússon, E., Gudmundsson, M. T., Roberts, M. J., Sigurðsson, G., Höskuldsson, F., and Oddsson, B.: Ice-volcano interactions during the 2010 Eyjafjallajökull eruption, as revealed by airborne imaging radar, J. Geophys. Res., 117, B07405, doi:10.1029/2012JB009250, 2012.

McElroy, C. T., Nowlan, C. R., Drummond, J. R., Bernath, P. F., Barton, D. V., Dufour, D. G., Midwinter, C., Hall, R. B., Ogyu, A., Ullberg, A., Wardle, D. I., Kar, J., Zou, J., Nichitiu, F., Boone, C. D., Walker, K. A., and Rowlands, N.: The ACE-MAESTRO instrument on SCISAT: description, performance, and preliminary results, Appl. Opt., 46, 4341-4356, 2007.

Michelsen, H. A., Manney, G. L., Irion, F. W., Toon, G. C., Gunson, M. R., Rinsland, C. P., Zander, R., Mahieu, E., Newchurch, M. J., Purcell, P. N., Remsberg, E. E., Russell III, J. M., Pumphrey, H. C., Waters, J. W., Bevilacqua, R. M., Kelly, K. K., Hintsa, E. J., Weinstock, E. M., Chiou, E.-W., Chu, W. P., McCormick, M. P., and Webster, C. R.: ATMOS version 3 water vapor measurements: Comparisons with observations from two ER-2 Lyman-a hygrometers, MkIV, HALOE, SAGE II, MAS, and MLS, J. Geophys. Res., 107, 4027, doi:10.1029/2001JD000587, 2002.

Mo, K. C.: Relationships between low-frequency variability in the southern hemisphere and sea surface temperature anomalies, J. Climate, 13, 3599-3610, 2000.

Murray, F. W.: On the computation of saturation vapor pressure, J. Appl. Meteorol., 6, 203-204, 1967.

Nakamae, K., Uchino, O., Morino, I., Liley, B., Sakai, T., Nagai, T., and Yokota, T.: Lidar observation of the 2011 Puyehue-Cordón Caulle volcanic aerosols at Lauder, New Zealand, Atmos. Chem. Phys., 14, 12099-12108, doi:10.5194/acp-14-12099-2014, 2014.

Newhall, C. G. and Self, S.: The Volcanic Explosivity Index (VEI): An estimate of explosive magnitude for historical volcanism, J. Geophys. Res., 1231-1238, 1982.

Petersen, G. N., Bjornsson, H., and Arason, P.: The impact of the atmosphere on the Eyjafjallajökull 2010 eruption plume, J. Geophys. Res., 117, D00U07, doi:10.1029/2011JD016762, 2012.

Pinto, J. P., Turco, R. P., and Toon, O. B.: Self-limiting physical and chemical effects in volcanic eruption clouds, J. Geophys. Res., 94, 11165-11174, 1989.

Prospero, J. M., Charlson, R. J., Mohnen, V., Jaenicke, R., Delany, C., Moyer, J., Zoller, W., and Rahn, K.: The atmospheric aerosol system: An overview, Rev. Geophys., 21, 1607-1629, 1983.

Pruppacher, H. R. and Klett, J. D.: Microphysics of clouds and precipitation, Springer, New York, 2010.

Pumphrey, H. C., Read, W. G., Livesey, N. J., and Yang, K.: Observations of volcanic $\mathrm{SO}_{2}$ from MLS on Aura, Atmos. Meas. Tech., 8, 195-209, doi:10.5194/amt-8-195-2015, 2015.
Randel, W. J., Moyer, E., Park, M., Jensen, E., Bernath, P., Walker, K., and Boone, C.: Global variations of $\mathrm{HDO}$ and $\mathrm{HDO} / \mathrm{H}_{2} \mathrm{O}$ ratios in the upper troposphere and lower stratosphere derived from ACE-FTS satellite measurements, J. Geophys. Res., 117, D06303, doi:10.1029/2011JD016632, 2012.

Rinsland, C. P., Gunson, M. R., Abrams, M. C., Lowes, L. L., Zander, R., Mahieu, E., Goldman, A., Ko, M. K. W., Rodriguez, J. M., and Sze, N. D.: Heterogeneous conversion of $\mathrm{N}_{2} \mathrm{O}_{5}$ to $\mathrm{HNO}_{3}$ in the post-Mount Pinatubo eruption stratosphere, J. Geophys. Res., 99, 8213-8219, 1994.

Schmidt, A., Witham, C. S., Theys, N., Richards, N. A. D., Thordarson, T., Szpek, K., Feng, W., Hort, M. C., Woolley, A. M., Jones, A. R., Redington, A. L., Johnson, B. T., Hayward, C. L., and Carslaw, K. S.: Assessing hazards to aviation from sulfur dioxide emitted by explosive Icelandic eruptions, J. Geophys. Res. Atmos., 119, 14180-14196, doi:10.1002/2014JD022070, 2014.

Schumann, U., Weinzierl, B., Reitebuch, O., Schlager, H., Minikin, A., Forster, C., Baumann, R., Sailer, T., Graf, K., Mannstein, H., Voigt, C., Rahm, S., Simmet, R., Scheibe, M., Lichtenstern, M., Stock, P., Rüba, H., Schäuble, D., Tafferner, A., Rautenhaus, M., Gerz, T., Ziereis, H., Krautstrunk, M., Mallaun, C., Gayet, J.F., Lieke, K., Kandler, K., Ebert, M., Weinbruch, S., Stohl, A., Gasteiger, J., Groß, S., Freudenthaler, V., Wiegner, M., Ansmann, A., Tesche, M., Olafsson, H., and Sturm, K.: Airborne observations of the Eyjafjalla volcano ash cloud over Europe during air space closure in April and May 2010, Atmos. Chem. Phys., 11, 2245-2279, doi:10.5194/acp-11-2245-2011, 2011.

Sears, T. M., Thomas, G. E., Carboni, E., Smith, A. J. A., and Grainger, R. G.: $\mathrm{SO}_{2}$ as a possible proxy for volcanic ash in aviation hazard avoidance, J. Geophys. Res. Atmos., 118, 56985709, doi:10.1002/jgrd.50505, 2013.

Sigmundsson, F., Hreinsdóttir, S., Hooper, A., Árnadóttir, T., Pedersen, R., Roberts, M. J., Óskarsson, N., Auriac, A., Decriem, J., Einarsson, P., Geirsson, H., Hensch, M., Ófeigsson, B. G., Sturkell, E., Sveinbjörnsson, H., and Feigl, K. L.: Intrusion triggering of the 2010 Eyjafjallajökull explosive eruption, Nature, 468, 426-430, 2010.

Sioris, C. E., Zou, J., McElroy, C. T., McLinden, C. A., and Vömel, H.: High vertical resolution water vapour profiles in the upper troposphere and lower stratosphere retrieved from MAESTRO solar occultation spectra, Adv. Space. Res., 46, 642-650, 2010 a.

Sioris, C. E., Boone, C. D., Bernath, P. F., Zou, J., McElroy, C. T., and McLinden, C. A.: ACE observations of aerosol in the upper troposphere and lower stratosphere from the Kasatochi volcanic eruption, J. Geophys. Res., 115, D00L14, doi:10.1029/2009JD013469, 2010b.

Sioris, C. E., Zou, J., Plummer, D. A., Boone, C. D., McElroy, C. T., Sheese, P. E., Moeini, O., and Bernath, P. F.: Upper tropospheric water vapour variability at high latitudes - Part 1 : Influence of the annular modes, Atmos. Chem. Phys. Discuss., 15, 22291-22329, doi:10.5194/acpd-15-22291-2015, 2015.

Soden, B. J., Wetherald, R. T., Stenchikov, G. L., and Robock, A.: Global cooling after the eruption of Mount Pinatubo: A test of climate feedback by water vapor, Science, 296, 727-730, 2002.

Solomon, S., Rosenlof, K. H., Portmann, R. W., Daniel, J. S., Davis, S. M., Sanford, T. J., and Plattner, G.-K.: Contributions of stratospheric water vapor to decadal changes in the rate of global warming, Science, 327, 1219-1223, doi:10.1126/science.1182488, 2010. 
Steele, H. M., Eldering, A., and Lumpe, J. D.: Simulations of the accuracy in retrieving stratospheric aerosol effective radius, composition, and loading from infrared spectral transmission measurements, Appl. Opt., 45, 2014-2027, 2006.

Stein, A. F., Draxler, R. R., Rolph, G. D., Stunder, B. J. B., Cohen, M. D., and Ngan, F.: NOAA's HYSPLIT atmospheric transport and dispersion modeling system, B. Am. Meteorol. Soc., 96, 2059-2078, doi:10.1175/BAMS-D-14-00110.1, 2015.

Stiller, G. P., Kiefer, M., Eckert, E., von Clarmann, T., Kellmann, S., García-Comas, M., Funke, B., Leblanc, T., Fetzer, E., Froidevaux, L., Gomez, M., Hall, E., Hurst, D., Jordan, A., Kämpfer, N., Lambert, A., McDermid, I. S., McGee, T., Miloshevich, L., Nedoluha, G., Read, W., Schneider, M., Schwartz, M., Straub, C., Toon, G., Twigg, L. W., Walker, K., and Whiteman, D. N.: Validation of MIPAS IMK/IAA temperature, water vapor, and ozone profiles with MOHAVE-2009 campaign measurements, Atmos. Meas. Tech., 5, 289-320, doi:10.5194/amt-5-289-2012, 2012.

Theys, N., Campion, R., Clarisse, L., Brenot, H., van Gent, J., Dils, B., Corradini, S., Merucci, L., Coheur, P.-F., Van Roozendael, M., Hurtmans, D., Clerbaux, C., Tait, S., and Ferrucci, F.: Volcanic $\mathrm{SO}_{2}$ fluxes derived from satellite data: a survey using OMI, GOME-2, IASI and MODIS, Atmos. Chem. Phys., 13, 59455968, doi:10.5194/acp-13-5945-2013, 2013.

Theys, N., De Smedt, I., Van Roozendael, M., Froidevaux, L., Clarisse, L., and Hendrick, F.: First satellite detection of volcanic OClO after the eruption of Puyehue-Cordón Caulle, Geophys. Res. Lett., 41, 667-672, doi:10.1002/2013GL058416, 2014.

Thomas, H. E. and Prata, A. J.: Sulphur dioxide as a volcanic ash proxy during the April-May 2010 eruption of Eyjafjallajökull Volcano, Iceland, Atmos. Chem. Phys., 11, 687-6880, doi:10.5194/acp-11-6871-2011, 2011.
Thomason, L. W., Moore, J. R., Pitts, M. C., Zawodny, J. M., and Chiou, E. W.: An evaluation of the SAGE III version 4 aerosol extinction coefficient and water vapor data products, Atmos. Chem. Phys., 10, 2159-2173, doi:10.5194/acp-10-2159-2010, 2010.

Uemera, N., Kuriki, S., Nobuta, K., Yokota, T., Nakajima, H., Sugita, T., and Sasano, Y.: Retrieval of trace gases from aerosol-influenced infrared transmission spectra observed by low-spectral-resolution Fourier-transform spectrometers, Appl. Opt., 44, 455-466, 2005.

Vanhellemont, F., Tetard, C., Bourassa, A., Fromm, M., Dodion, J., Fussen, D., Brogniez, C., Degenstein, D., Gilbert, K. L., Turnbull, D. N., Bernath, P., Boone, C., and Walker, K. A.: Aerosol extinction profiles at $525 \mathrm{~nm}$ and $1020 \mathrm{~nm}$ derived from ACE imager data: comparisons with GOMOS, SAGE II, SAGE III, POAM III, and OSIRIS, Atmos. Chem. Phys., 8, 2027-2037, doi:10.5194/acp-8-2027-2008, 2008.

Vernier, J.-P., Fairlie, T. D., Murray, J. J., Tupper, A., Trepte, C., Winker, D., Pelon, J., Garnier, A., Jumelet, J., Pavalonis, M., Omar, A. H., and Powell, K. A.: An advanced system to monitor the 3D structure of diffuse volcanic ash clouds, J. Appl. Meteor. Climatol., 52, 2125-2138, 2013.

Wang, X.: Remote sensing of the vertical profile of cirrus cloud effective particle size, $\mathrm{PhD}$ thesis, University of California at Los Angeles, Los Angeles, 2008.

Woodhouse, M. J., Hogg, A. J., Phillips, J. C., and Sparks, R. S. J.: Interaction between volcanic plumes and wind during the 2010 Eyjafjallajökull eruption, Iceland, J. Geophys. Res.-Sol. Ea., 118, 92-109, doi:10.1029/2012JB009592, 2013.

Woodhouse, M. J., Hogg, A. J., Phillips, J. C., and Rougier, J. C.: Uncertainty analysis of a model of wind-blown volcanic plumes, Bull. Volcanol., 77, 83, doi:10.1007/s00445-015-0959-2, 2015. 